Walisongo: Jurnal Penelitian Sosial Keagamaan

Vol. 28 No.1 (2020) pp. 87-106

DOI: $10.21580 /$ ws.28.1.5190

\title{
The Dynamics of the Khalwatiyah Sufi Order in North Luwu, South Sulawesi
}

\author{
Abdain Abdain, ${ }^{1 *}$ Rahmawati Beddu, ${ }^{2}$ Takdir Takdir ${ }^{3}$ \\ ${ }^{1,2,3}$ Institute Agama Islam Negeri Palopo, Indonesia
}

\begin{abstract}
This paper discusses the dynamic of the Khalwatiyah Sufi Order in North Luwu, South Sulawesi. The type of research is qualitative. The research focuses were the dynamic between the leader (caliphs) and followers of the Khalwatiyah Sufi Order. The authors gathered data through library and field research. The techniques to obtain the data were observation, interview, and documentation. The instruments used were interview guidelines, writing instruments, and mobile phones to record audio and video data. The results showed that: 1) The absence of caliphs who guide and teach the Khalwatiyah followers; 2) The assumption of a Khalwatiyah follower said that today's society is modern material life; 3) The absence of regeneration of these Khalwatiyah followers; 4) The young people from the Khalwatiyah family attending tertiary institutions and following various social organizations, they are more likely to develop their organizations than follow the Khalwatiyah ritual. 5) The effect of the environment.
\end{abstract}

Artikel ini membahas dinamika Tarekat Khalwatiyah di Luwu Utara, Sulawesi Selatan. Jenis penelitian ini adalah kualitatif. Fokus penelitian adalah dinamika antara pemimpin (khalifah) dan pengikut Tarekat Khalwatiyah. Penulis mengumpulkan data melalui studi pustaka dan penelitian lapangan. Teknik pengumpulan data adalab observasi, wawancara, dan dokumentasi. Instrumen yang digunakan adalah pedoman wawancara, alat tulis, dan telepon genggam untuk merekam data audio dan video. Hasil penelitian ini menunjukkan

\footnotetext{
*Corresponding Author: Abdain Abdain (abdain@iainpalopo.ac.id), IAIN Palopo, Balandai, Bara, Balandai, Palopo, Palopo, South Sulawesi, Indonesia 91914

ISSN 0852-7172 (p) 2461-064X (e)
}

(C) 2020 by the Authors, published by Walisongo: Jurnal Penelitian Sosial Keagamaan https://journal.walisongo.ac.id/index.php/walisongo 
bahwa: 1) Tidak ada khalifah yang membimbing dan mengajarkan amalan pengikut Khalwatiyah; 2) Asumsi seorang pengikut Khalwatiyah mengatakan bahwa kehidupan masyarakat saat ini adalah material yang modern; 3) Tidak ada kaderisasi para pengikut Khalwatiyah; 4) Kaum muda dari keluarga Khalwatiyah kuliah di perguruan tinggi dan mengikuti berbagai organisasi kemasyarakatan, lebih mengembangkan organisasi daripada mengikuti ritual Khalwatiyah. 5. Pengaruh lingkungan.

Keywords: dynamics; followers of Khalwatiyah; Khalwatiyah Sufi Order

\section{Introduction}

South Sulawesi has a faithfully religious Muslim population. In the history of Islam in the region, there had been two central-local states, Gowa and Bone. Patron client systems embedded in social interactions among the Makassarnese and Buginese contributed to the rapid dissemination of Islam in the region where its influence within the palaces and the population cannot be dissociated from the role of local noblemen. Since its appearance in the 1820s, the Khalwatiyah Sufi Order has been repeatedly challenged by an array of learned Muslim leaders (ulama) working with Bone's district government (Pelras, 2001, pp. 107-135).

Meanwhile, Sufism and Sufi order which is in the Indonesian context called Sufi order is an inevitable part of the spread of Islam in Indonesia. The Sufism model is easy to accept because it has familiar traits with the pre-Islamic Nusantara people's spiritual life. Spirituality, which is based on efforts to develop an inner aspect of human life, has proved that it attracts the masses' attention and forms Islam's character in Nusantara, especially before the 20th century when Wahhabi started to influence Indonesia. It is not surprising that various sufi orders have flourished in Indonesia and gained significant Indonesian Muslims' significant followers. Sufi Order can also explain the intellectual link that connects the archipelago's Muslim community with International Muslim society (Fanani, 2012). 
Therefore, Islamic religious practices of Indonesian Muslims in Indonesia are close to mystical Sufism. This mystical ritual style for some performed in the form of a Sufi order (tarekat). Each sufi order has an organization of followers who branch out into several streams following thoughts and leaders (Zahro, 2004, p. 45). One of the sufi orders is the Khalwatiyah. The followers of the sufi order are required to obey the sufi order rules. They have to be submissive in carrying out practices through their participation in the Shari'a rituals and observance. Compliance incorporated in the tradition of the Khalwatiyah tradition turns out to be local wisdom in the relationship between followers with the leader (caliph) of the sufi order so that the relationship between the two is very adjacent. The obedience of the followers of this sufi order maintains the existence of this sufi order until now. Concerning the community accepting or rejecting the Khalwatiyah in its development, the sufi order still maintains its existence as a Sufistic school.

Nevertheless, the development is not significant, it can even be lost due to several things. One of them is reduced and interrupted regeneration. For example, if parents are followers of Khalwatiyah, their children will not necessarily follow them. This case is found in North Luwu. Moreover, the latest generation is most likely affected by modernization. Science and technology were more likely to influence social changes in their life. In social life, the Sufi order followers continue to associate and adapt to society in general. Seeing and reflecting on this condition, the researcher wants to explore further where the Sufi order Khalwatiyah followers in North Luwu and their social changes.

This research type is a qualitative descriptive study equipped with preparing research instruments, searching and collecting data with various techniques. The location of the research is North Luwu. The research focuses on the dynamics between the leader (khalifah) of the Khalwatiyah Order and their followers. The data collection instruments were: observation guidelines, interview guides, cameras, recording devices. By visiting several villages, that there are followers of the Khalwatiyah Sufi 
Order. Processing techniques include data reduction, data editing, and inductive and deductive analysis.

\section{History and Existence of the Khalwatiyah Sufi Order in North Luwu}

The emergence and development of the Khalwatiyah Sufi Order in the archipelago, especially in South Sulawesi, can be based on two versions. First, the one who brought and spread the Khalwatiyah Sufi Order's teachings in South Sulawesi was Muhammad Yusuf bin Abdullah Abu Mahasin al-Taj al-Khalwati al-Makassari, commonly called Sheikh Yusuf al-Makassari in 1670 AD. This Sufi order developed in Gowa, Makassar, and surrounding areas indeed.

The second opinion states that this teachings' emergence and development originated from Sumbawa, Nusa Tenggara, around 1820 through the noble service of Sheikh Abdullah al-Munir, a noble Muslim descendant from Bugis Bone. To disseminate the teaching, Sheikh Abdullah al-Munir taught his son named Sheikh Muhammad Fidayl bin Abdullah al-Munir, Sheikh Abdul Razak (who had the title of Haji Palopo), and Abdullah. Then Abdullah led and mandated his three sons, Sheikh Muhammad Saleh bin Abdullah, Sheikh Muhammad Amin bin Abdullah, and Sheikh Ibrahim bin Abdullah to teach the Khalwatiyah Sufi Order (Wahab, 2014, p. 57).

The Khalwatiyah Sufi Order developed in Maros and its surroundings. In spreading the Sufi order, Sheikh Abdullah Munir's successors received positive responses and sympathy from the Muslim community at the time and had many followers. The influence of generation seen especially in Maros was the influence of Sheikh Abdul al-Razak and his son named Haji Abdullah bin Abdul al-Razak who are taught from generation to generation to the present. When Haji Abdullah died in 1931, the leadership of Khalwatiyah was bequeathed to his three children, namely Haji Muhammad Saleh, called Puang Lompo (died in 1967), and Haji Muhammad Amin, called Puang Naba (died in 1970), and Haji Ibrahim, known as Puang. Solong (died in 1982). Even though three of Haji 
Abdullah's sons were appointed as caliphs, but Haji Muhammad Shaleh was the eldest child, he was still elder in making policies. Thus there was always regeneration of leadership. Haji Abdullah's influence extends to several areas in South Sulawesi including the Luwu-Palopo region (an interview with Subaedah, the follower of the Khalwatiyah -Puang Kaburu's wife-, Masamba, June 17 ${ }^{\text {th }}, 2019$ ).

It has to be noted that there are two versions of the Khalwatiyah that has developed in Indonesia. First, the Khalwatiyah Sufi Order, which has a genealogical chain through Sheikh Yusuf al-Makassari. He developed this Sufi order in the Makassar area and its surroundings. Second, the Khalwatiyah Sufi Order was the same as through Sheikh Abd al-Shamad al-Palimbani (1703-1788) from Abd al-Karim al-Sammani. This Sufi order developed in the Palembang area and its surroundings (Abdillah, 2011, p. $31)$.

Both of them developed in various regions besides Sulawesi, such as Riau, East Kalimantan, Ambon, and West Irian. As for South Sulawesi, the Bugis and Makassar are the majority. The name of Khalwatiyah Yusuf Sufi Order based on Shaykh Yusuf al-Makassari, and the Khalwatiyah Samman Sufi Order taken from the name of an 18th century Medina Sufi Muhammad al-Samman. These two branches of the Sufi order emerged as entirely different orders. Each is independent has no much in common unless the name (Nurhikmah, 2017).

There are differences in terms of practice, organization, and social composition of followers. The Khalwatiyah Yusuf performs its $d h i k r$ and wirid silently in the heart, while the Khalwatiyah Samman does in a loud and ecstatic voice. The latter is very centralized. All teachers submit to Maros' central leadership, while the first does not have a central leadership. Local branches of the Khalwatiyah Samman Sufi order often have a worship place (mushalla in Arabic term, or langgar in Javanese term). They tend to isolate themselves from followers of other Sufi orders. 
In contrast, the followers of Khalwatiyah Yusuf do not have them and are free to mix with people who are not members of the Sufi order. As this teaching spreads in society, membership also grows up. Their followers came from different social strata. It was even noted that the Khalwatiyah Yusuf Sufi order came from the Makassar aristocracy, including the ruler of the last Gowa work, Andi Ijo Sultan Muhammad Abdul Qadir Aidid (in power 1940-1960). The Khalwatiyah Samman Sufi order is more populist in terms of both style and social composition; most of its followers are villagers (Mulyati \& Bakhtiar, 2005, p. 74). The followers from different ethnic groups or social strata impress that the Khalwatiyah is well accepted by the community, especially in South Sulawesi.

We can't spread the entry process of this teaching into North Luwu from Palopo. The process of entering Palopo has a different explanation from several sources, one of which is the explanation expressed by Prof. Dr. H.M. Said Mahmud, Lc., MA. The teachings of the Sufi order started and developed in Bone around 1886. Then the teachings were brought to Luwu by the followers of the Khalwatiyah called Haji Palopo. There are two versions of history about entering Khalwatiyah into Luwu. First, Khalwatiyah teaching was brought to the palace of the ledge directly. Second, the Haji Palopo brought the Khalwatiyah teachings to Amassangan (so called Malangke), as the center kingdom. In the palace at Langkanai Palopo, after that spread to East Luwu Malili and Ongkona areas, next spread, flourished in Baebunta, after developing in Baebunta at the same time in Masamba, and precisely in Masamba, it spread a lot until this time (An interview with H.M. Said Mahmud, the professor of philosophy at IAIN Palopo and the leader of Khalwatiyah, Palopo, July $\left.18^{\text {th }}, 2019\right)$.

Although the teachings of this Sufi order spread and developed in the Palopo region, it does not mean that it does not experience obstacles and challenges. When the initial entry of this Sufi order to Luwu (Palopo), it was not easy, and indeed some of the Muslims prevented it at that time because it was considered new and heresy. This can be seen from the objection letter 
sent by Haji Abdullah addressed to the Governor of South Sulawesi around the 1930s regarding the treatment of Ramli Haji (Qadi Palopo-Luwu), which prevented a population of about a thousand people from swearing to become followers of the Khalwatiyah (Rahman, 2009, p. 27).

Other information states that the Khalwatiyah Sufi Order's teachings to the Luwu (Palopo) were brought directly by Puang Haji Pabbiring from Maros, South Sulawesi Province, and was received directly by Grandma Puang, the Hawang family. It expressed by his grandson (Puang Taherong) who said before he died in Bugis language:

Tellumpenni mabenniku ko ritanae, engkatu matu riaseng Puang Pabbiring caliph, tiwi tareka 'khalwatiyae yes manenna iko appoku. Mattama Korek Manekko (three days after I was in the ground (buried), there will be a caliph who brings the Khalwatiyah, all of you grandchildren, follow the teachings) (an interview with Puang Taherong the leader of Khalwatiyah, Palopo, 21st July 2019).

Puang Hajj Pabbiring invited and taught the teachings of the Khalwatiyah to the Luwu-Palopo people at that time, were known as the village of Libukang. Another source also mentioned that the Khlawatiyah Sufi order's teachings into Luwu were brought by Haji Palopo precisely in Pattimang, Malangke, Luwu (now North Luwu). Then Haji Palopo developed and taught in Palopo, precisely in Libukang (an interview with H.M. Said Mahmud, the professor of philosophy IAIN Palopo and the leader of Khalwatiyah, Palopo, July 18 ${ }^{\text {th }}$, 2019).

When this Sufi order entered Libukang Palopo and had many followers, it expanded to several areas in Luwu Raya, including the North Luwu, Masamba. There are several opinions about the development and inclusion of the Khalwatiyah Sufi Order in North Luwu. One of the khalifah Khalwatiyah said that the inclusion of the Khalwatiyah Sufi Order in Masamba North Luwu was brought by Puang Haji Daeng Malebbang. Puang Haji Daeng Malebbang commonly called Puang Lebbang. He is one of the Khalwatiyah Sufi Order followers from Patte'ne, Maros, South Sulawesi. It was this arrival of the Lebbang community that spread the teachings of the Khalwatiyah Sufi Order so that it spread in several areas in 
North Luwu. However, the Khalwatiyah Sufi Order's existence is not all equal (An interview with Puang Tamrin, Khalifah Khalwatiyah the leader of Khalwatiyah, Masamba, June 19 ${ }^{\text {th }}$, 2019).

Puang Tamrin also said another version that some even said that because of the extensive influence of $\mathrm{H}$. Muhammad Saleh (Puang Lompo), the development of Khalwatiyah reached Tanah Luwu. In the land of Luwu, it was first received by one of Belopa and then arrived in Palopo. Someone from Penggoli, the city of Palopo (still in Luwu, at that time) received it, called Puang Labbang, (his grave in Libukang), conveying to his family in Masamba, North Luwu. As Tamrin stated, Puang Labbang Ambena Salolo brought Khalwatiyah to Masamba. The one who brought the teachings of the Khalwatiyah Sufi Order in Masamba was Puang Labbang. He was the one who spread and taught it in Masamba. (an interview with Puang Tamrin, Khalifah Khalwatiyah, the leader of Khalwatiyah, Masamba, June $\left.19^{\text {th }}, 2019\right)$.

According to the Puang Taherong explanation, the Khalwatiyah Sufi Order's teachings were not conveyed to ordinary people but were delivered and taught to highly respected people and nobles. So that the arrival of this Sufi order in Masamba was immediately conveyed to the elder and included the nobility, Andi Mabbayan (Puang Opu), in Baliase, Andi Massikati (Puang Opu) in Uraso, Andi Muhiddin (Puang Opu) in Uraso, and Puang Tobaga in Baliase. These were the first to accept and teach the Khalwatiyah Sufi Order in North Luwu Masamba. All of them were nobles (An interview with Puang Tamrin, Khalifah Khalwatiyah the leader of Khalwatiyah, Masamba, June 19 ${ }^{\text {th }}, 2019$ ).

This period followed several caliphs simultaneously, namely Puang Tondo Kalla in Baliase, Puang Muhammad Saleh in Paladan, Puang Opu Ati in Karawak Lantang, Tallang Masamba, Puang Opu Aji in Korro Baliase, Masamba. Puang Opu Aji was with Matinroe ri Mecca (sleeping in Mecca) because he died in the holy land while performing the pilgrimage to become a caliph (an interview with Saleh, the son of Puang Toba, Masamba, June 20 $0^{\text {th }}, 2019$ ). 
Furthermore, following some of the caliphs, among others, Puang Andi Junaid (Puang Opu) in Uraso, Puang Imang in Indo Koro, Puang Suki in Baebunta, Puang Anta and Puang Tamrin at Nanna Mappedeceng, Puang Daeng Mattunrong in Ketulungan Sukamaju, and Puang Daeng Mattunrong in Wotu (an interview with Andi Fitri, the son of Puang Opu Uraso, Masamba, Juli 2019).

The development of the teachings of the Khlawatiyah Sufi Order in North Luwu is inseparable from the role of some of the leaders/caliphs mentioned so that it makes followers increasingly growing. They need the caliphs to guide them. The caliphs from year to year until now have been being appointed. The figures who contributed to developing the teachings of the Sufi order in Luwu Raya seen in Table 1.

\section{Existence of Followers of the Khalwatiyah of North Luwu}

The development and dissemination of Khalwatiyah teachings have reached out to its followers throughout the North Luwu. This research will only describe several areas in North Luwu which are the basis of followers of the Khalwatiyah Sufi Order, including:

\section{a. Lantang Tallang, Masamba}

Since the Khalwatiyah Sufi Order's entry in this village, almost $80 \%$ of peoples followed in 1990s, but over time around the 2000s, followers began to decrease. Data obtained in the field found that the followers of this Sufi order have started to drop. Even followers only make up around $8 \%$ of the population (An interview with Bahris, the inhabitant at Desa Lantang Tallang, June $\left.10^{\text {th }}, 2019\right)$. From about $8 \%$, it is dominated by the rest are women or about four people are men. It was stated by one of the followers of the Sufi order that in Karawak there were many followers. However, only four men join the Sufi order, but many women (Interview with Naisa, Khalwatiyah follower, Masamba, June $16^{\text {th }}, 2019$ ). Khalwatiyah followers in this village average of those aged around 60 years and over and no data found followers aged 50 years and under 50 years. 


\section{ABDAIN ABDAIN, RAHMAWATI BEDDU, TAKDIR TAKDIR}

Table 1.

The Caliph of the Khlawatiyah Sufi Order in North Luwu

\begin{tabular}{|c|c|c|c|}
\hline No. & Name & Origin & \\
\hline 1 & Puang Andi Massikati (Puang Opu) & Masamba/Uraso & Passed away 1960s \\
\hline 2 & Puang Andi Mabbayan (Puang Opu) & Masamba/Baliase & Passed away 1970 s \\
\hline 3 & Puang Andi Muhiddin (Puang Opu) & Masamba/Uraso & $\begin{array}{l}\text { The son of Andi } \\
\text { Massikati }\end{array}$ \\
\hline 4 & Puang Tobaga (Puang Kaburu) & Masamba/Baliase & Passed away 1980 s \\
\hline 5 & Puang Andi Junaid (Puang Opu) & Masamba/Uraso & Passed away 2018 \\
\hline 6 & Puang Haji Ambe Bora & Masamba/Nanna & \\
\hline 7 & Puang Muhammad Saleh & Masamba/Paladan & \\
\hline 8 & Puang Imang & Masamba/Indokoro & \\
\hline 9 & Puang Anta (Puang Ambe Dira) & Masamba/Nanna & Passed away in 2019 \\
\hline 10 & Puang Tamrin (Puang Ambe Yuli) & Masamba/Nanna & \\
\hline 11 & Puang Suki (Baebunta) & Masamba/Baebunta & \\
\hline 12 & Puang Ahyar Daeng Manai & Sukamaju/Tondolangi & \\
\hline 13 & Puang Haji Daeng Manabba & Masamba/Wotu & \\
\hline 14 & Puang daeng Mattunrong & Masamba/Ketulungan & \\
\hline 15 & Puang Pabbiring & Palopo/Libukang & \\
\hline 16 & $\begin{array}{l}\text { Puang Haji Daeng Malebbang (Puang } \\
\text { Lebbang) }\end{array}$ & Palopo/Libukang & \\
\hline 17 & Puang Atte & Palopo/Penggole & $\begin{array}{l}\text { The son of Puang } \mathrm{H} \\
\text { Daeng Malebbang }\end{array}$ \\
\hline 18 & Puang Timo & Palopo & $\begin{array}{l}\text { The father of Puang } \\
\text { Muhammad Karimun }\end{array}$ \\
\hline 19 & Puang Haji Kasim & Palopo & \\
\hline 20 & Puang Nurung & Palopo & \\
\hline 21 & Puang Daeng situru & Palopo & $\begin{array}{l}\text { The son of Puang } \\
\text { Haji Kasim }\end{array}$ \\
\hline 22 & Puang Nenek Juhanna & Palopo & \\
\hline 23 & $\begin{array}{l}\text { Puang Muhammad Saleh (Puang } \\
\text { Guru) }\end{array}$ & Palopo & \\
\hline 24 & Puang Madaming & Palopo & $\begin{array}{l}\text { The son of Puang } \\
\text { Muhammad Saleh }\end{array}$ \\
\hline 26 & Puang Muhammad Karimun & Palopo & \\
\hline 27 & Puang Taherong & Palopo & \\
\hline 28 & $\begin{array}{l}\text { Puang Prof. H.M. Said Mahmud, Lc., } \\
\text { MA }\end{array}$ & Palopo & \\
\hline 29 & Puang Lamunda & Palopo & \\
\hline 30 & Puang Daeng Pabbare & Palopo-Penggoli & \\
\hline 31 & Puang Syarifuddin Wahab & Palopo & \\
\hline 32 & Puang lahami Daeng Mangngati & Palopo & \\
\hline 33 & Puang Sirajuddin S.Ag. & Palopo & \\
\hline
\end{tabular}

Source: From various sources 


\section{b. Paladan, Masamba}

This village is inhabited by about 50 families who $100 \%$ are followers of this Khalwatiyah Sufi Order. In the 2000s, many generations of Khalwatiyah followers left their homeland with different needs and interests, such as lectures and migrants. Because they are married to other couples in the village, some are no longer bound by worship practice according to the Khalwatiyah Sufi Order's teachings. As one of these followers stated that his children who went abroad and especially those already in college, were no longer practicing Khalwatiyah teachings, perhaps because of school or the environment. (An interview with Karim, Imam Masjid dan figure of the Khalwatiyah, Paladan, June $\left.16^{\text {th }}, 2019\right)$.

\section{c. Baliase, Masamba}

The Khalwatiyah Sufi Order in the village still exists and still has many followers. Yet, as with other regions in North Luwu, most followers are aged 50 years and over and are less desirable by millennials, so it is almost said that followers each year decrease due to not regeneration.

\section{d. Nanna, Mappedeceng, and Porodoa}

The two hamlets are neighbors and are the basis or have followers most Khalwatiyah. His followers are not only the older generation but also followed by the younger generation and even children. The factors that cause this Sufi order still exist and survive because of parents who require children to be followers of the Khalwatiyah and because there is still a murshid or caliph who guides and teaches them. In Nanna and Porodoa, there are murshid or caliphs, namely Puang Haji Ambe Bora (Death: 1989), Puang Anta (Death: 2019), and Puang Tamrin. They were instrumental in developing and defending the Sufi order's teachings in North Luwu, specifically in Nanna and Porodoa Mappedeceng, Mappedeceng.

\section{e. Uraso, Mappedeceng}

Uraso, Mappedeceng, is also the basis of the Khalwatiyah; this is because, in this region, three caliphs have been instrumental in teaching 
and defending these teachings amidst intense information and changes in society. Among the caliphs who were instrumental in teaching and maintaining the Khalwatiyah teachings in this region were Puang Andi Massikati (Puang Opu Uraso), Puang Andi Muhiddin (Puang Opu), and Puang Andi Junaid, who could also be called Puang Opu.

\section{f. Tondolangi, Sukamaju}

Puang Ahyar Daeng Manai was a responsible caliph for the existence of the Khalwatiyah Sufi Order. The Khalwatiyah Sufi Order in the village still exists around $70 \%$ of the total population through his effort. (An interview with Andi Fitri, the son of Puang Opu Uraso, Masamba, July $\left.17^{\text {th }}, 2019\right)$.

\section{The Social Change Dynamics within the Sufi Order}

Social change is an issue that will never halt. There are groups of people who are optimistic about social changes and those pessimistic. Social change involves social science studies covering three different dimensions of time: past, present, and future. For this reason, social problems related to the issue of social change are difficult to overcome and anticipate. However, social issues that arise in society are mostly a consequence of social change. Even more than that, environmental issues are often related to social change (Martono, 2012, p. vii). Various dimensions of life experience redefinition and differentiation, which show the relative nature of the social practice (Abdullah, 2009). Social change and globalization will affect a group, both religious groups and social groups. According to Irwan Abdullah, what is seen is a life shift from ethical processes to aesthetics (Abdullah, 2009). According to Atho Mudzhar in M Rasyid Ridha, Islamic Studies with a sociological approach have five influential, namely; 1) Study the influence of religion on social change, 2) Study of social structure and change on understanding religious teachings or religious concepts. 3) The study of the community's level of religious experience, namely Islamic studies with a sociological approach, 
can evaluate how far religious teachings are practiced by the community, through observations and surveys about how intensely they carry out their religious rituals and so on. 4) study of the social patterns of Muslim societies. 5) The study of community movements fosters and supports religious life that covers spiritual life and Sufism (Ridla, 2012).

Sufi order is a journey made by sālik (Sufi order follower) by purifying himself towards God or travel that must be taken to get closer so that someone as close as possible to God (Editorial Team, 1993, p. 66). In the beginning, several things made the Sufi order appealing to its followers, and developed rapidly. First, some Sufi order followers tend to carry out as much worship as possible (Nasution, 1992). The Sufi order leaders teach dhikir that can lead their followers to a direct meeting with God, whose opinion was rejected by orthodox scholars (F. Rahman, 1984, p. 217). Second, the sufi order leaders' authority and charisma have a powerful influence and appeal for the people who want to deepen their spirituality. The Sufi order Khalwatiyah has developed in various regions in Indonesia. Including in North Luwu. The followers of this sufi order in the North Luwu were initially counted as many followers, taking part in religious rituals such as $d h i k r$ every night, carrying out maulid and Isrā 'mirāj. But lately, the follower is slowly rarely following the ritual. Several things influence this condition:

First, no leader or caliph guides and teaches the Khalwatiyah Order. In the past, when the caliphs were still alive, this Sufi order still had many followers. If there were followers who no longer followed the teachings of the Khalwatiyah, they were immediately summoned by the Puang (caliph) to be advised. (An interview with Andi Fitri, the son of Puang Opu Uraso, Masamba, July $\left.17^{\text {th }}, 2019\right)$.

Second, there is assumption of a Khalwatiyah follower said that today's society is modern often classified as the post industrial society (Ni'am, 2015, pp. 123-137). Material life in such a way, with technological devices that are all mechanical and automatic, to meet human needs must try as much as possible, both in financing family life and 
school fees for their children. So, in carrying out rituals or remembrance in totality cannot be fulfilled because the time used for worship is also used to find the necessities of life to fulfill the needs of life. This is according to what Muhammad Shaleh revealed, the following:

In some regions, the followers of Khalwatiyah remain invisible because they are busy making a living, so they do not follow the dhikr together (an interview with Muhammad Saleh, the follower of Khalwatiyah, Baliase, June $\left.17^{\text {th }}, 2019\right)$

Third, the most important thing here is that there is no regeneration from the Khalwatiyah followers. Due to the young people from the average level of education from outside the region, they cannot follow the congregation's practices, whether they are following the obedience.

Fourth, besides this, the influence is young people from the Khalwatiyah family attending tertiary institutions' lectures following various social organizations such as the Muhammadiyah organization. When returning to their regions, especially in the Paladan, the Masamba, they are more likely to develop their organizations than follow the Khalwatiyah ritual. It is as stated by Erna as follows:

Most of the young people here, when they go to college they join the organization so that when they return to their villages, they develop their organizations as if they were part of the Muhammadiyah organization. So rarely follow Khalwatiyah recitation which is usually done in the mosque after the Fajr and Isha prayers (an interview with Erna, the follower of Khalwatiyah, Baliase, Paladan, June $15^{\text {th }}, 2019$ ).

It is following the advanced formal education system with a highquality education that can change the mindset. People who have higher education will be more rational in thinking and acting because of future orientation. The desire to get a better lot will encourage social and cultural changes in society.

Fifth, the Jama'ah Tabligh's presence aggressively invites the public to the mosque to worship so that the congregational prayers performed by the Khalwatiyah congregation from house to house are slowly being seen again. People prefer mosques. This situation made the Khalwatiyah ritual 
services no longer as frequent as before, although they were still carried out both in a congregation and individually.

Sixth, the influence of the environment, where the youth who are now no longer live in a place where the average community of Khalwatiyah followers follows the lifestyle and conditions of the people they live. According to what was stated by one of the caliphs Khalwatiyah (Tamrin) as follows: tae na sesuai ajaranta to nangai torro (An interview with Tamrin, the follower of Khalwatiyah, Nanna, June $18^{\text {th }}$, 2019).

It means he lives in a place that is not following our teachings (Khalwatiyah's teachings). Environmental influences are very influential in the occurrence of social change. Besides, the authoritative and charismatic leader as a leader who is emulated, respected, and respected by the community brings influence in social dynamics.

According to Hamzah, the story is that the status quo started to change after Abdullah's death in 1931. The influence of the fatwa then became more evident among members of the Sufi order. As noted by Hamzah, a descendant of Abdullah, the fatwa resulted in intimidation of the Sufi order's followers and the caliph's family members (Hamzah, 2007).

Therefore, it seems that the formal leaders regard Abdullah's passing as a new opportunity to challenge the reputation of the Khalwatiyah fundamentally. Nevertheless, with time, the fatwa resulting from the Bone meeting had a little lasting impact on the Sufi order's reputation, even though Abdullah was no longer with his followers. Before he passed away, Abdullah mandated his three sons as the order(Ruslan, 2008).

\section{The Khalwatiyah and Socio-Political Dynamics}

1930 is an era of political and social transformations through the spread of various new ideas from abroad-including nationalism, capitalism, socialism, and Islamic modernism. As leaders of the Sufi order with large local followers, Abdullah and his descendants were challenged 
with the necessity to answer to these influential new features in a swiftly shifting world of public discourse.

The leaders of the Khalwatiyah have confirmed triumph "in exercising religious authority" performed by Sufism in terms of the contexts of local culture and politics in South Sulawesi. These persons could integrate spiritual practices that preserved continuities with pre-Islamic traditions and fashioned a sense of group commonality. The fact that the Sufi order has been persistent in attracting followers after the fall of the New Order in 1998 further points to its enduring plea. While Islamic teachings regard spiritual and intellectual attainment as the main requirements for umma leadership, previous leaders' cumulative authority has permitted contemporary leaders who do not have the same scientific qualifications as their predecessors to remember their followers' devotion. In this phase, like their predecessors, they have been assisted by the doctrine of total obedience of the followers towards the master and traditional BugisMakassar attitudes towards hereditary descent (Ubaedillah, 2014, 2017).

The New Order was very much concerned about obtaining political support from the Muslim majority. As early as the 1970s, it became evident to the Sufi order that Suharto's policy towards Islam would open up new avenues of opportunity. Its followers scattered across the region thus came to be seen as a potential political bargain the leaders could employ to obtain government patronage (the order's bargaining chip was that the members could act as a vote mobilizer for Golkar). In return for the Sufi order support, the state was willing to ensure that they remained protected. This bargain was viewed as an excellent opportunity by the caliph of the order in an era where there was still great potential for political prejudice between state and Islam. For the Sufi order leadership, the New Order regime's coming provided opportunities to consolidate its tradition and development. Suharto's connection to Maros's sufi order leadership was another key to understanding developments during the New Order period. During his earlier military career, Suharto was stationed in the Makassar near Maros, where he formed a personal relationship with the leader of the sufi order. 
According to the current caliph (Andi Syadjaruddin Malik), this was why the order came to identify itself as a supporter of Golkar-the official political machine of Suharto's New Order. (Ubaedillah, 2014).

Another exciting fact within the Sufi order in terms of the sociopolitical realm dynamics was that the Khalwatiyah followers' obedience to their leader in politics tends to decrease compared to religious matters. A thesis focused on losing the Khalwatiyah leader's son in the 2014 general election (Afriandy, 2015, p. 57). The followers are more fanatical about the Sufi order's religious teachings than their leader's political preference. It is consistent with the explanation of Martin van Bruinessen that within the Sufi order there are two perceptions regarding its relationship with politics. First, the Sufi order in the colonial era was the basis of opposition, which meant a direct involvement in politics. For example, in 1925 all sufi order were banned after a Kurdish nationalist rebellion led by the Naqsyabandiyah sufi order leaders. The official ban will be applied to contextually, although the Sufi order's activities have recently undergone new developments. Even stricter bans were in place in the (late) Soviet Union. In the Soviet Union's Muslim republics, the sufi order network has indeed been the most important underground opposition.

On the other hand, the second perception considers the development of the sufi order as a symptom of depoliticization, as an escape from social and political responsibility. In this view, the sufi order is more oriented towards heavenly affairs than world problems. Critics of sufi order emphasized the ascetic $(z u h d)$ and afterlife orientation; In an effort to get closer to God, the sufi order generally distances themselves from society (khalwah, 'uzlah). If "traditional" Muslims (Aswaja) are considered more conservative, accommodating and apolitical than modernist Muslims, sufi order is considered the most conservative of the conservative, and the one who shuns political attitudes the most. This view, as we shall see, is too simple. However, it cannot be denied that there is a close relationship between the depoliticization of Islam (as seen in Indonesia over the last three decades) and the fertile process of development of the sufi order (Bruinessen, 1992). 


\section{Conclusions}

The existence of the Khalwatiyah Sufi Order in North Luwu couldn't be separated from several key figures who first brought it. Prof. Said Mahmud thought that H. Palopo was the first to bring this Khalwatiyah gift. The Khalwatiyah Sufi Order's teachings to the Luwu (Palopo) were brought directly by Khalwatiyah figures named Puang Haji Pabbiring from Maros, South Sulawesi. They were received directly by Grandma Puang, the Hawang family. All areas in North Luwu that used to have many followers, now a few places whose followers still survive, include Paladan about $95 \%$, Porodoa about $99 \%$, Nanna about $90 \%$, Tondolagi about $70 \%$, and other areas that still have the follower of the Khalwatiyah Sufi Order.

The dynamics of the Khalwatiyah Sufi Order in North Luwu: 1) The absence of caliphs who guide and teach the Khalwatiyah followers; 2) The assumption of a Khalwatiyah follower said that today's society is modern material life; 3) The absence of regeneration of these Khalwatiyah followers; 4) The young people from the Khalwatiyah family attending tertiary institutions and following various social organizations, they are more likely to develop their organizations than follow the Khalwatiyah ritual. 5) The effect of the environment.[w]

\section{References}

Abdillah, M. A. (2011). Tasawuf Kontemporer Nusantara: Integrasi Tasawuf Ibn 'Arabi dan al-Ghazali: Ajaran Tasawuf Syekh Hizboel Wathony, Mursyid Tarekat Khalwatiyah Akmaliy. Jakarta: INA Publikatama.

Abdullah, I. (2009). Konstruksi dan Reproduksi Kebudayaan. Yogyakarta: Pustaka Pelajar.

Afriandy, A. (2015). Kepatuhan Pengikut Ajaran Khalwatiyah Samman terhadap Pemimpinnya pada Pemilu Legislatif 2014. Universitas Hasanuddin Makassar.

Bruinessen, M. van. (1992). Tarekat dan Politik: Amalan untuk Dunia atau Akhirat? Pesantren, 3-14. 
Editorial Team. (1993). Tarekat. In Ensiklopedi Islam - 5. Jakarta: Ichtiar Baru Van Hoeve.

Fanani, A. (2012). Ajaran Tarekat Syattariah dalam Naskah Risalah Shattariyah Gresik. Walisongo, 20(2), 347-370. https://doi.org/10.21580/ws.20.2.203

Hamzah, A. N. (2007). Tarekat Khalwatiyyah Samman: Ajaran dan Strategi Dakwah para Khalifahnya. Ujung Pandang: La Macca Press.

Martono, N. (2012). Sosiologi Perubahan Sosial: Perspektif Klasik, Modern, Posmodern, dan Poskolonial. Jakarta: RajaGrafindo Persada.

Mulyati, S., \& Bakhtiar, A. (2005). Mengenal dan Memahami Tarekattarekat Muktabarah di Indonesia. Jakarta: Kencana Predana Media Group.

Nasution, H. (1992). Falsafat dan Mistisisme dalam Islam. Jakarta: Bulan Bintang.

Ni'am, S. (2015). Tasawuf di Tengah Perubahan Sosial (Studi tentang Peran Tarekat dalam Dinamika Sosial-Politik di Indonesia). Harmoni, 15(2), 123-137.

Nurhikmah. (2017). Eksistensi Dakwah Ajaran Tarekat Khalwatiyah Samman di Kabupaten Wajo. Kuriositas, 11(2), 147-166. https://doi.org/10.35905/kur.v10i2.591

Pelras, C. (2001). Religion, Tradition, and the Dynamics of Islamization in South Sulawesi. In A. Gordon (Ed.), The Propagation of Islam in the Indonesian-Malay Archipelago (pp. 107-135). Kuala Lumpur: Malaysian Sociological Research Institute.

Rahman, A. (2009). Qut Qulub al-Arifin: Suntingan Teks Karya Abdullah al-Bugisi al-Marusi, Khalifah Sammaniyah, Sulawesi Selatan. Jakarta: Puslitbang Lektur Keagamaan Badan Litbang dan Diklat Departemen Agama RI.

Rahman, F. (1984). Islam (A. Mohammad (trans.)). Bandung: Pustaka.

Ridla, R. (2012). Sosiologi Hukum Islam (Analisis terhadap Pemikiran M. Atho' Mudzhar). Al-Ihkam: Jurnal Hukum dan Pranata Sosial, 7(2), 293-304. https://doi.org/10.19105/al-lhkam.v7i2.330

Ruslan. (2008). Meluruskan Pemahaman Makna Tarekat. Makassar: Pustaka al-Zikra. 
Ubaedillah, A. (2014). Khalwatiyah Samman in South Sulawesi, Indonesia (1920 - 1988) Exercising Authority in An Era of Change. Asian Journal of Social Science, 42, 620-640.

Ubaedillah, A. (2017). The Rise of the Khalwatiyah Sammān Sufi Order in South Sulawesi: Encountering the Local, Escaping the Global. Studia Islamika, 24(2), 213-245. https://doi.org/10.15408/ sdi.v24i2.4186

Wahab, R. A. (2014). Bunga Rampai Tarekat Khalwatiyah. Yogyakarta: Pustaka Al-Zikra.

Zahro, A. (2004). Lajnah Bahtsul Masai'l 1926-1999, Tradisi Intelektual NU. Yogyakarta: LKiS. 